\title{
Indoor Air Quality Investigation at Primary Classrooms in Hamirpur, Himachal Pradesh, India
}

\author{
Venu Shree, Bhanu M. Marwaha and Pamita Awasthi
}

Abstract: Two schools in Hamirpur (Himachal Pradesh, India) having hybrid ventilation (ceiling fan) were selected for indoor and outdoor air quality investigation. Investigated parameters include temperature, relative humidity, $\mathrm{CO} 2$, and $\mathrm{PM}_{2.5}$ for both indoor and outdoor air quality. The average concentrations of $\mathrm{CO}_{2}$, and $\mathrm{PM}_{2.5}$ are estimated for indoor and outdoor air quality. Result shows that adopted building performance is not good in comparison with designed ones. The indoor concentrations of various pollutants are found to be higher in comparison with outdoor, so there is an urgent need to reduce the levels of pollutants inside the primary classrooms.

Keywords: Indoor Air Quality (IAQ); $\mathrm{PM}_{2.5} ; \mathrm{CO}_{2}$; Ventilation, India

\section{Introduction}

ir pollution has been identified as the major Aenvironmental threat in India, as a significant population is exposed to the highest levels of air pollutants in the world (Smith,1993 \& WHO,1999). According to World Health Organisation (WHO), IAQ is considered as 8th most important risk factor towards the burden of disease. Indoor Air Pollution (IAP) could be described as the presence of more than 900 air pollutants, in indoor, of higher concentration than their respective permissible limits. Presence of these air pollutants depend upon the building location, outdoor air quality, type of activities in close proximities of buildings, building construction materials used, indoor furnishes and finishes, and user activities carried out in a specific indoor area (Taneja et al., 2008). According to Jones (1999), there is a direct relationship between occupant health and indoor air pollution as occupant may experience airborne pollutants through breathing, eating and interaction with their sense organs i.e. eyes, nose, and skin. Maroni et al. (1995) have stated that adverse IAQ would result in a number of physical ailments and symptoms like shortness of breath, headache, fatigue, sinus congestion, skin irritation, throat, eye and nose irritation, dizziness, nausea etc. The causes of indoor air pollution are a concoction of chemicals in air, and physical and biological factors of indoor environment along with reduced ventilation. Most of the time, sources of pollutants are outdoors but sometimes they are present indoors as well.

IAQ in school buildings has acquired excessive attention, as children spend large span of daytime in their classrooms. Children are more vulnerable to airborne diseases as they inhale more volume of air in relation to their body size (Ciencewicki and Jaspers, 2007). They are delicate in their early age of growth because of their physical constitution and breathing pattern, and therefore, more susceptible to health effects of air pollution than adults (Maesano et al., 2003).

In comparison to adults, children breathe at closer level to the ground, therefore, they inhale denser and heavy airborne contaminants. Occupants (children, teachers and staff) at school buildings are 4 times closer as compared to office buildings; therefore, they need better quality of indoor air. It is significantly evident that longterm exposure of children to poor IAQ in classrooms may directly affect and cause respiratory diseases like asthma along with headaches, allergies and indirectly lead to impacts on learning ability of the children (Maesano et al., 2013 \& Daisey et al., 2003).

Our indoor environments used to be considered better and safer than the outdoor environments, being cleaner, comfortable, on the obvious ground of providing shelter from harmful pollutants of ambient environment. Therefore, majority of air quality monitory systems in the world, are designed for outdoor uses. Unfortunately, these outdoor standards for permissible air pollutants levels cannot be consider as reliable indicators for indoor exposures (Lawrence \& Taneja, 2005). Assessment of risk to the children from indoor air pollution should ideally include the measurement of air pollutants concentration in the micro-environment as well as macro-environment of the particular spatial area.

Hilly regions are considered to be pollution free and having good outdoor environment. Keeping this in mind, this study has been carried out to evaluate the concentration levels of indoor air pollutants (i.e. CO2, VOCs and PM2.5) in schools of Hamirpur town at Himachal Pradesh, India. The survey was conducted in primary classroom of two schools. This study attempts to understand the relationship between indoor and outdoor concentration of air pollutants in summer seasons as well as to provide the information about the present IAQ scenario in Hamirpur (HP), India.

Dueto the unavailability of IAQ standards in the Indian context, American Society of Heating, Refrigerating and Air Conditioning Engineers (ASHRAE) standard 62.12004 has been adopted for analysing of $\mathrm{CO}_{2}$ and EPA guidelines are used to monitor concentration of $\mathrm{PM}_{2.5}$ and VOCs in IAQ of primary classrooms of both the schools (Table 1). 


\begin{tabular}{|l|l|}
\hline Pollutants & Permissible standards \\
\hline PM 2.5 & $65 \mu \mathrm{g} / \mathrm{m} 3$ [EPA (for 24 hrs exposure)] \\
\hline VOCs & $20 \mathrm{ppm}[$ EPA (for 24 hrs exposure)] \\
\hline CO2 & $1000 \mathrm{ppm}[$ ASHRAE (62.1-2004)] \\
\hline
\end{tabular}

Table 1: Indoor Air Quality Guidelines

\begin{tabular}{|l|l|l|}
\hline \multicolumn{2}{|l|}{ School 'A' } & School 'B' \\
\hline \multicolumn{2}{|l|}{ Spatial Parameters } & \multicolumn{2}{|l|}{} \\
\hline Floor & Ground & Ground \\
\hline $\begin{array}{l}\text { Room Size (1 x b } \\
\text { x h) }\end{array}$ & $4.09 \times 1.89 \times 2.0$ & $6 \times 7.2 \times 3.3$ \\
\hline $\begin{array}{l}\text { Occupancy Dura- } \\
\text { tion }\end{array}$ & 9.30 a.m. -3.00 a.m. & 9.30 a.m. $-3: 00$ p.m. \\
\hline Occupants & 10 & 30 \\
\hline No. of Doors & 1 & 1 \\
\hline $\begin{array}{l}\text { Size of Doors (b } \\
\text { x h) }\end{array}$ & $0.75 \times 1.8$ & $0.9 \times 2$ \\
\hline No. of Windows & 1 & 4 \\
\hline $\begin{array}{l}\text { Size of Windows } \\
\text { b x h) }\end{array}$ & $0.68 \times 1.2$ & $1.2 \times 2$ \\
\hline Type of Ventilation & Hybrid - Single side & $\begin{array}{l}\text { Hybrid - Cross Ven- } \\
\text { tilation }\end{array}$ \\
\hline Lighting type & Daylight \& Artificial & Daylight \& Artificial \\
\hline Non-spatial Parameters & Concrete & Concrete \\
\hline Roofing & Brick Wall & Brick Wall \\
\hline $\begin{array}{l}\text { Wall construction } \\
\text { material }\end{array}$ & Cement Plaster & Paint, Cement Plaster \\
\hline $\begin{array}{l}\text { Floor construction } \\
\text { material }\end{array}$ & Concrete & Enamel \\
\hline Wall finish & Cement Plaster & Cement Plaster \\
\hline Type of paint & Wood & Synthetic \\
\hline Ceiling finish & Synthetic & Synthetic \\
\hline Type of Doors & Synthetic & Wood \\
\hline Type of Windows Board \\
\hline Type of Furniture \\
\hline $\begin{array}{l}\text { Type of teaching } \\
\text { boards }\end{array}$ & Black Board & Black \\
\hline
\end{tabular}

Table 2: Detailed of Spatial and Non-spatial Parameters of Classrooms

\section{Methodology}

\section{Site Description}

This study aimed to investigate the present scenario of indoor and outdoor concentration of air pollutant assessment in different settings. The selected schools are different in associations of their location (state highway and rural road), land use pattern (commercial and residential) design of school (adopted and designed), and the age of building. The unit of study was grade 1 classroom from primary section of children, aged 6-7 years. The survey for indoor and outdoor investigation of air quality conducted for six working days in each school during summer season May-June, 2018. School A is located beside a national highway in the suburb of a town. The classroom has one single-glazed window and is provisioned with ceiling fan-based hybrid ventilation; whereas School B is situated in a rural residential setup beside a state highway, that is a connecting road and the classroom has four singly glazed windows with provision of hybrid ventilation through a ceiling fan and the provision of cross ventilation.

\section{Sampling and Analysis}

The pollutants, considered as parameters of interests, were carbon dioxide ( $\mathrm{CO} 2)$, relative humidity ( $\mathrm{RH})$, PM2.5, temperature, wind velocity and percentage of fresh air. The Forbix Semicon air quality monitor and dust meter were used for the measurements. The indoor and outdoor air movements were also measure by HTC hotwire anemometer. All measuring instruments were placed at the centre of the class on the height of $1.0 \mathrm{~m}$ above floor at indoor and outdoor both. Pollutants were measured at this height because target group i.e. children breathe at this low level and consequently are prone to inhale heavy air pollutants.

Carbon dioxide, temperature, RH, PM2.5 and VOCs were continuously monitored before and after lunch during a day to analyse the change in pollutants due of children activity. The indoor and outdoor average concentration of pollutants were measured in occupied classrooms for six days of summer season.

\section{Results and Discussion}

The study has been carried out to evaluate $\mathrm{CO} 2$, PM2.5 and VOCs, but measurement shows very less concentration of VOCs in the classrooms. Hence, the results pertaining to VOCs are not presented. Figure 1 shows the indoor and outdoor average temperature and humidity levels measured at six random working days of a school. The indoor temperature level of the first class at School A (Adopted) ranged from $30-33^{\circ} \mathrm{C}$, that is out of thermal comfort range $\left(22^{\circ} \mathrm{C}-28^{\circ} \mathrm{C}\right)$ for the occupants (ASHARE Comfort Chart). Thermal discomfort may decrease the productivity and learning ability among children. Similarly, the indoor relative humidity levels range from $17.5 \%$ to $55 \%$.

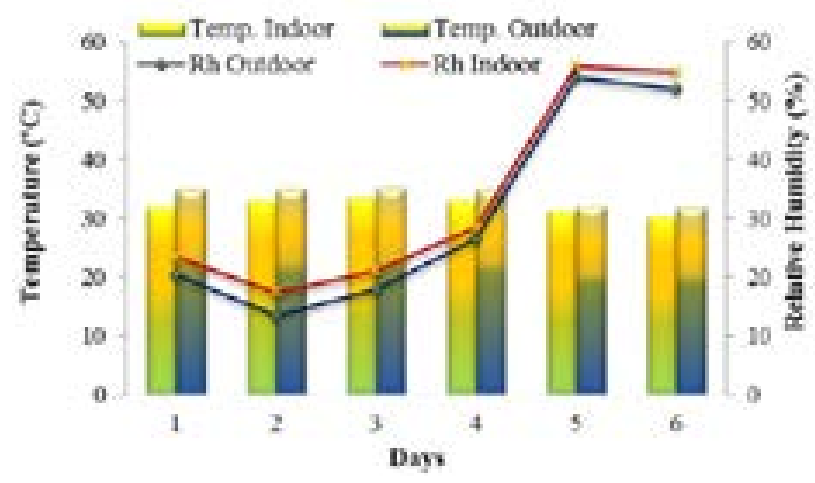

Figure 1: Temperature and Relative Humidity of school 'A' at May-June 2018 
Outdoor temperature level was found to be significantly high whereas outdoor relative humidity level was less. That means the building envelop is providing some interventions in building microclimate but is not very effective. Figure 2 shows the indoor-outdoor level of pollutants i.e. $\mathrm{CO} 2$ and PM2.5. Indoor concentration level of $\mathrm{CO} 2$ was found to be higher than the outdoor but within the prescribed range of ASHRAE standards. Both outdoor and indoor PM2.5 level exceeded the 24-h average concentration of EPA standards. The concentration of $\mathrm{PM}_{2.5}$ ranges from 283-568 $\mu \mathrm{g} / \mathrm{m}^{3}$. High level of $\mathrm{PM}_{2.5}$ in Hamirpur is mainly caused by vehicle exhaust emissions, pollen, air shadow zones and due to poor maintenance of the classrooms.

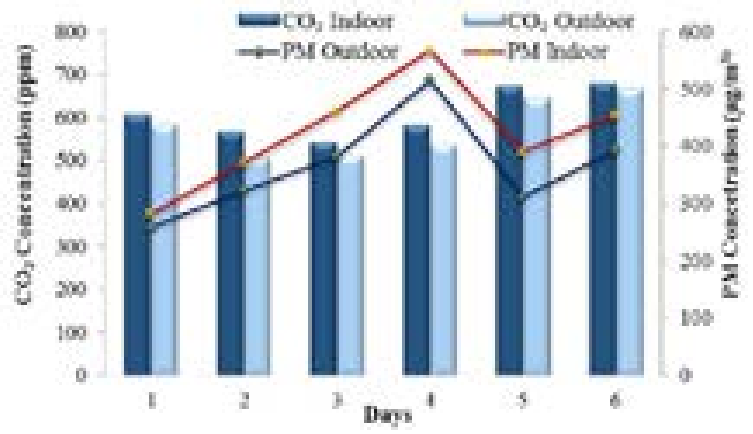

Figure 2: $\mathrm{CO}_{2}$ and $\mathrm{PM}_{2.5}$ at school 'A' during May-June 2018 (Summer Season)

The high outdoor PM2.5 concentration is caused by transport of heavy vehicles like bus, trucks in the vicinity and affect the indoor level as there are no natural barrier in terms of parking or landscape between the road and building.

In school ' $\mathrm{B}$ ', which is a designed school, the concentrations of pollutants were found to be of entirely different pattern. Indoor temperature of the room varied from $28.5^{\circ}$ to $33.7^{\circ} \mathrm{C}$,

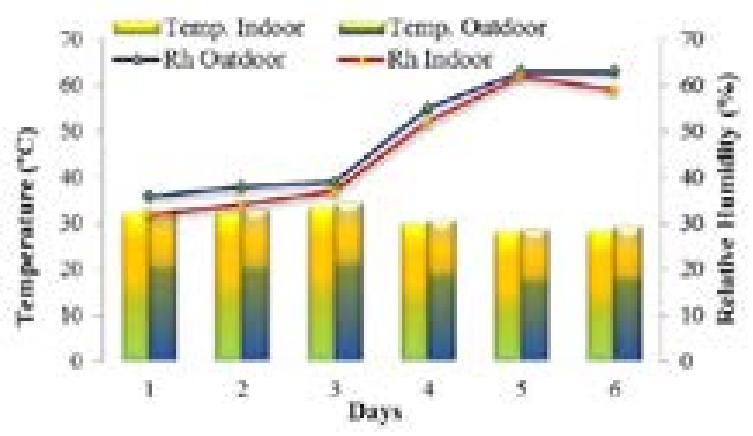

Figure 3: Temperature and Relative Humidity of school 'B' at May-June 2018 (Summer Season)

Whereas outdoor temperature varied between 28.3 to $33.3^{\circ} \mathrm{C}$. Indoor relative humidity was within the comfort range (30\% to $65 \%$ ) and varied between $32-62 \%$ in working days.

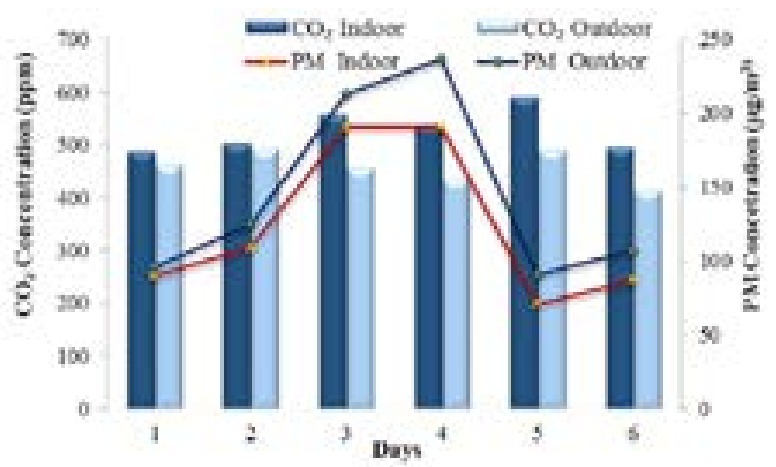

Figure 4: $\mathrm{CO}_{2}$ and $\mathrm{PM}_{2.5}$ at school 'B' during May-June 2018 (Summer Season)

$\mathrm{CO} 2$ concentration during school working days varied from 435-590 ppm and outdoor $\mathrm{CO} 2$ concentration 413-557 ppm. The indoor particulate concentration monitored at max reached to $191 \mu \mathrm{g} / \mathrm{m}^{3}$. The building envelop provides a significant protection to particulate as maximum outdoor particulate concentration was much higher, $237 \mu \mathrm{g} / \mathrm{m}^{3}$.

$\mathrm{CO} 2$ concentration remained low when the classroom was unoccupied in morning, lunchtime and after schools. The occupant densities at both the schools were as per the ASHARE standard 62-1989 (i.e. 50 people/ $100 \mathrm{~m}^{2}$ ) as well as their respective education board standards. The major problem of indoor air pollution in classrooms of primary schools at Hamirpur (H.P.) was found because of particulate matter that exceeded the permissible limit by 9.5 times. These particulates of 2.5 aerodynamic sizes are very dangerous as they may directly affect the alveoli deep in the lung. In primary schools, children are in the growing age and all their organs are in developing stage, therefore the $8 \mathrm{hr}$ exposure to this high particulate concentration is very dangerous for them.

Figure 5 shows the percentage of fresh air in both the schools for summer season. In all six monitored days, the percentage of fresh air at school 'A' remained below $55 \%$ and in school 'B' min fresh air percentage was $70 \%$ and it sometimes reaches up to $93 \%$. The main reason observed for this is inadequate ventilation (cross ventilation) and maintenance of building (Cleaning). Windows were provided with fixed wire mash surface that provides particulates a surface to settle. When these settled particles encountered moisture, they are prone to give birth to fungi and biological pollutants and block the sieves of wire mash. Therefore, the airflow through the window openings gets clogged. This whole process results in less intake of fresh air inside the classrooms.

Second reason for less ventilation was, not making a provision of cross ventilation in the classroom. As school ' $\mathrm{B}$ ' is a designed school, they had provided door and window opening to ensure cross ventilation in classrooms. Nevertheless, in school 'A', being an adopted building design, the provision of cross ventilation had 
not been provided. Therefore, the children of school 'A' were exposed to polluted air during the whole day.

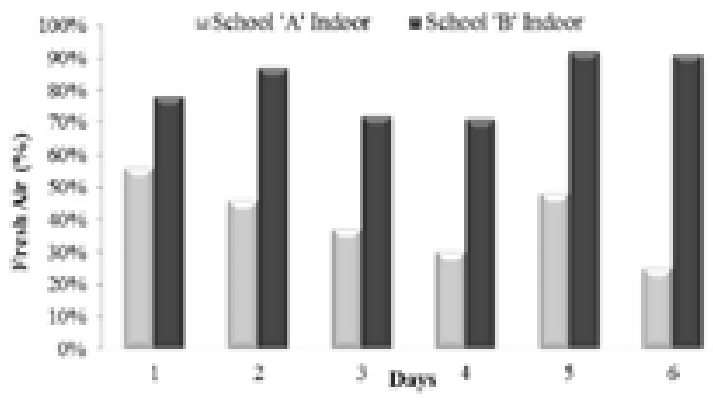

Figure 5: Availability of fresh Air in different school during May-June 2018 (Summer Season)

\section{Conclusion}

This paper presented the results of experimental investigations at two schools for indoor air quality in naturally ventilated primary classrooms that were not providing a healthy learning environment for children. The measurement and interpretation of indoor carbon dioxide and particulate matter can provide useful information on building indoor air quality and ventilation. The investigation found a simple solution of lack of fresh air in one school by door and window openings, and lack on landscape.

The average PM min levels at school located in national highway were recorded to be higher than the school located at rural road. This gives the evidence that in urban areas, pollution levels are high due to heavy traffic and vehicular emission.

Provisions of open space and setbacks also have significant impact on the concentration of particulates as the school without open space had higher concentration of particulate matters (School A). This indicated that provision of open spaces reduces the level of pollutants entering the classroom indoors and allows the pollutants to dilute in the open space provided in school premises.

To reduce the children's exposure to high concentration of particulate, the top five recommendations are; (1) provide cross ventilation (2) provision of landscape (3) regular cleaning of wire mash surface of windows, (4) replace the doors and windows, and (5) provision of open spaces should be made in school building.

\section{Acknowledgements}

The parties associated and involved for providing data and guidance are thankfully acknowledged.

Venu shree and Bhanu M. Marwaha belongs to Department of Architecture, National Institute of Technology, Hamirpur, India.

Corresponding address: venushree8o@gmail.com

Pamita Awasthi belongs to Department of chemistry, National Institute of Hamirpur, India.

\section{Reference}

Annesi-Maesano, I., Agabiti, N., Pistelli, R., Couilliot, M. F., \& Forastiere, F. (2003). Subpopulations at increased risk of adverse health outcomes from air pollution. European Respiratory Journal, 21(40 suppl), 57s-63s.

Annesi-Maesano, I., Baiz, N., Banerjee, S., Rudnai, P., Rive, S., \& SINPHONIE Group. (2013). Indoor air quality and sources in schools and related health effects. Journal of Toxicology and Environmental Health, Part B, 16(8), 491-550.

American Society of Heating, Refrgerating and air conditioning Engineers (ASHRAE) standard 62.1, 2004.

Ciencewicki, J., \& Jaspers, I. (2007). Air pollution and respiratory viral infection. Inhalation toxicology, 19(14), 1135-1146.

Daisey, J. M., Angell, W. J., Apte, M. G. (2003). Indoor air quality, ventilation and health symptoms in schools: an analysis of existing information. Indoor air, 13(1), 53-64.

Jones, A. P. (1999). Indoor air quality and health. Atmospheric environment, 33(28), 4535-4564

Lawrence, A. J., \& Taneja, A. (2005). An investigation of indoor air quality in rural residential houses in India-A case study. Indoor and Built Environment, 14(3-4), 321-329.

Maroni, M., Seifert, B., \& Lindvall, T. (Eds.). (1995). Indoor air quality: a comprehensive reference book (Vol. 3). Elsevier.

Smith, K. R. (1993). Fuel combustion, air pollution exposure, and health: the situation in developing countries. Annual Review of Energy and the Environment, 18(1), 529-566.

Taneja, A., Saini, R., \& Masih, A. (2008). Indoor air quality of houses located in the urban environment of Agra, India. Annals of the New York Academy of Sciences, 1140(1), 228-245.

WHO Air Management Systems (ANIS) World Health organization. Geneva (1999). 